\title{
Correction to: Biogeographic traits of dimethyl sulfide and dimethylsulfoniopropionate cycling in polar oceans
}

Zhao-Jie Teng ${ }^{1+}$, Qi-Long Qin ${ }^{1+}$, Weipeng Zhang ${ }^{2}$, Jian Li ${ }^{1}$, Hui-Hui Fu ${ }^{2,3}$, Peng Wang ${ }^{2,3}$, Musheng Lan ${ }^{4}$, Guangfu Luo ${ }^{4}$, Jianfeng He ${ }^{4}$, Andrew McMinn ${ }^{5}$, Min Wang ${ }^{2}$, Xiu-Lan Chen ${ }^{2,3}$, Yu-Zhong Zhang ${ }^{1,2,3}$, Yin Chen ${ }^{2,6^{*}}$ and Chun-Yang Li $\mathrm{i}^{2,3^{*}}$

Correction to: Microbiome 9, 207 (2021). https://doi.org/10.1186/s40168-021-01153-3

Following the publication of the original article [1], the author reported that there is an error in one of the authors name. The name of the 8th co-author of this article should be "Guangfu Luo", not "Guangfu Lu".

The original article has been updated.

\section{Author details}

'State Key Laboratory of Microbial Technology, Marine Biotechnology Research Center, Shandong University, Qingdao 266237, China. ${ }^{2}$ College of Marine Life Sciences, Institute for Advanced Ocean Study, Ocean University of China, Qingdao 266003, China. ${ }^{3}$ Laboratory for Marine Biology and Biotechnology, Pilot National Laboratory for Marine Science and Technology (Qingdao), Qingdao 266373, China. ${ }^{4}$ The Key Laboratory for Polar Science MNR, Polar Research Institute of China, Shanghai 200136, China. ${ }^{5}$ Institute for Marine and Antarctic Studies, University of Tasmania, Hobart, Tasmania, Australia. ${ }^{6}$ School of Life Sciences, University of Warwick, Coventry, UK.

Published online: 09 November 2021

\section{Reference}

1. Teng Z, Qin QL, Zhang W, Li J, Fu HH, Wang P, et al. Biogeographic traits of dimethyl sulfide and dimethylsulfoniopropionate cycling in polar oceans. Microbiome. 2021;9(1):207. https://doi.org/10.1186/s40168-021-01153-3.

* Correspondence: Y.Chen.25@warwick.ac.uk; Icy@ouc.edu.cn

${ }^{\dagger}$ Zhao-Jie Teng and Qi-Long Qin contributed equally to this work.

${ }^{2}$ College of Marine Life Sciences, Institute for Advanced Ocean Study, Ocean University of China, Qingdao 266003, China

Full list of author information is available at the end of the article

C C The Author(s). 2021 Open Access This article is licensed under a Creative Commons Attribution 4.0 International License, which permits use, sharing, adaptation, distribution and reproduction in any medium or format, as long as you give appropriate credit to the original author(s) and the source, provide a link to the Creative Commons licence, and indicate if changes were made. The images or other third party material in this article are included in the article's Creative Commons licence, unless indicated otherwise in a credit line to the material. If material is not included in the article's Creative Commons licence and your intended use is not permitted by statutory regulation or exceeds the permitted use, you will need to obtain permission directly from the copyright holder. To view a copy of this licence, visit http://creativecommons.org/licenses/by/4.0/. The Creative Commons Public Domain Dedication waiver (http://creativecommons.org/publicdomain/zero/1.0/) applies to the data made available in this article, unless otherwise stated in a credit line to the data. 